INTERNATIONAL JOURNAL OF RESEARCHES IN BIOSCIENCES, AGRICULTURE AND TECHNOLOGY (C) VISHWASHANTI MULTIPURPOSE SOCIETY (Global Peace Multipurpose Society) R. No. MH-659/13(N) www.vmsindia.org

\title{
ICHTHYOFAUNAL DIVERSITY IN KRISHNA RIVER IN SATARA DISTRICT, MAHARASHTRA, INDIA
}

\author{
R. G. Patil and M. P. Gujar \\ Dept. of Zoology, Lal Bahadur Shastri College, Satara. \\ ramraopati121@yahoo.com
}

\begin{abstract}
:
River Krishna is an important river in India as it travels through three states Maharashtra, Karnataka and Andhra Pradesh of India. Krishna river originates at Mahabaleshwar, District Satara (Maharashtra). The river has importance due to use of water for drinking, agriculture and irrigation purpose. In addition it is also rich in the fish fauna. Ichthyofaunal diversity in Krishna River in Satara district was studied during the period of two years from October 2012 to September 2014. Fishes were collected from different sites of river in Satara district with the help of local fisherman. Totally 73 fish species were observed during the present study. Out of these species five endangered, seven near threatened, forty seven least concern, three vulnerable and nine not evaluated one are data deficient.
\end{abstract}

Keywords:- Krishna river, Ichthyofauna

\section{Introduction:}

Krishna River is the main river of Satara district approx. $172 \mathrm{kms}$. of river course falls inside the district. The geographical location of Satara district is North latitudes 17.5 to 18.11 and East longitude 73.33 to 74.54 . The total geographical area of the Krishna basin in Maharashtra is $69,425 \mathrm{~km}^{2}$ (Satish, 2012) and that of Satara district is $10,816 \mathrm{~km}^{2}$.

Fish fauna of this river was studied in Satara district at Wai by Kharat et al. (2012) and observed 51 fish species. Freshwater fish diversity was studied by different scientists such as Sakhare V.B. (2001) in Jawalgaon reservoir, Sreekantha and Ramchandra (2005) in Linganamakki reservoir Sharavathi river, Goswami and Mankodi (2010) in reservoir Nayari II Rajkot district, Solanki et al. (2011) in Sanjay Sagar reservoir, Jadhav et al. (2011) in
Koyana river, Patil et al. (2011) in Dhom dam, Jitesh et al. (2011) in Isapur reservoir, Mahor (2011) in freshwater reservoir, Tighra, Rankhamb (2011) in Godavari river at Mudgal in district Parbhani, Thirumala (2011) in Bhadra reservoir of Karnataka, Tawseef et al. (2012) in Halali reservoir, Nath and Deka (2012) in Chandubi tectonic lake of Assam, Kadam et al. (2012) in Bori river, Nagma and Khan (2013) in district Bijnor in Western Utter Pradesh and Rao et al (2013) in river Champavati.

\section{Material and Methods:}

The Fish species were collected with the help of local fishermen during the period of two year from October 2012 to September 2014. The fishes were identified with the help of Standard keys (Misra, 1962; Day, 1887; Jayram, 2010; and Talwar and Jhingran, 1991).

\section{Results and Discussion:}

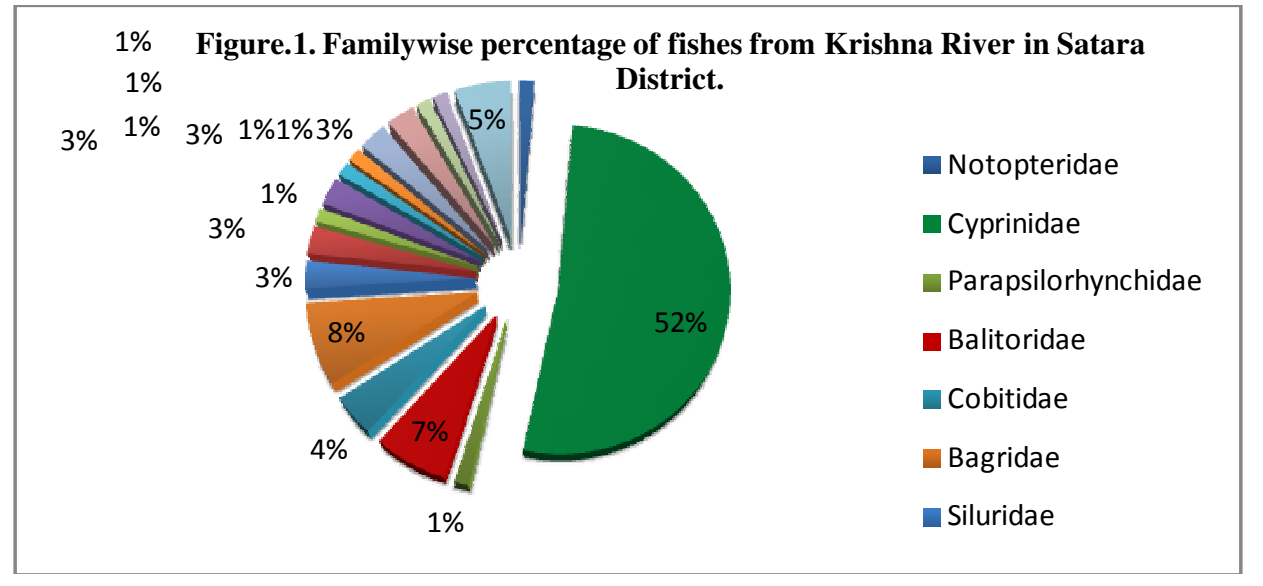


Table. 1- Fish Species collected from Krishna River in Satara District.

\begin{tabular}{|c|c|c|}
\hline \multicolumn{2}{|l|}{ Order /Family/ Species } & \multirow[t]{2}{*}{ IUCN red list status } \\
\hline Order- Osteoglossiformes & & \\
\hline Family- Notopteridae & 1. $\quad$ Notopterus notopterus & LC \\
\hline \multicolumn{3}{|l|}{ Order- Cypriniformes } \\
\hline \multirow[t]{38}{*}{ Family- Cyprinidae } & 2. Hypophthalmichthys molitrix & NT \\
\hline & 3. Salmophasia boopis & LC \\
\hline & 4. Salmophasia novacula & $\mathrm{LC}$ \\
\hline & 5. Salmophasia clupeiodes & $\mathrm{NE}$ \\
\hline & 6. Barilius barna & LC \\
\hline & 7. Barilius bendelisis & LC \\
\hline & 8. Danio malabaricus & LC \\
\hline & 9. Devario aequipinnatus & LC \\
\hline & 10. Rasbora daniconius & LC \\
\hline & 11. Ctenopharyngodon idellus & $\mathrm{NE}$ \\
\hline & 12. Cyprinus carpio & VU A2ce \\
\hline & 13. Tor tor & NT \\
\hline & 14. Tor khudree & EN A2acde \\
\hline & 15. Osteobrama vigorsii & LC \\
\hline & 16. Osteobrama cotia & $\mathrm{NE}$ \\
\hline & 17. Rohtee ogilbii & LC \\
\hline & 18. Puntius amphibius & DD \\
\hline & 19. Puntius jerdoni & LC \\
\hline & 20. Puntius sahyadriensis & LC \\
\hline & 21. Puntius sarana subnusutus & $\mathrm{NE}$ \\
\hline & 22. Puntius sarana & LC \\
\hline & 23. Puntius sophore & LC \\
\hline & 24. Puntius ticto & LC \\
\hline & 25. Gonoproktopterus curmuca & EN A2acd \\
\hline & 26. Gonoproktopterus kolus & VU A2acd \\
\hline & 27. Cirrhinus fulungee & LC \\
\hline & 28. Cirrhinus mrigala & LC \\
\hline & 29. Cirrhinus reba & LC \\
\hline & 30. Catla catla & $\mathrm{NE}$ \\
\hline & 31. Labeo rohita & LC \\
\hline & 32. Labeo calbasu & $\mathrm{LC}$ \\
\hline & 33. Labeo boggut & LC \\
\hline & 34. Labeo boga & LC \\
\hline & 35. Schismatorhynchos nukta & EN A2acd+3cd \\
\hline & 36. Crossocheilus latius & LC \\
\hline & 37. Garra bicornuta & NT \\
\hline & 38. Garra mullya & LC \\
\hline & 39. Garra gotyla & LC \\
\hline Family- Parapsilorhynchidae & 40. Parapsilorhynchus discophorus & VU B1ab(iii) \\
\hline \multirow[t]{5}{*}{ Family- Balitoridae } & 41. Acanthocobitis mooreh & $\mathrm{NE}$ \\
\hline & 42. Nemachilichthys rueppelli & LC \\
\hline & 43. Noemacheilus anguilla & $\mathrm{NE}$ \\
\hline & 44. Schistura denisoni & LC \\
\hline & 45. Indoreonectes evezardi & LC \\
\hline \multirow[t]{3}{*}{ Family- Cobitidae } & 46. Botia striata & EN B2ab(iii) \\
\hline & 47. Lepidocephalichthys thermalis & LC \\
\hline & 48. Lepidocephalichthys guntea & $\mathrm{LC}$ \\
\hline \multicolumn{3}{|l|}{ Order - Siluriformes } \\
\hline \multirow[t]{6}{*}{ Family- Bagridae } & 49. Rita rita & LC \\
\hline & 50. Sperata seenghala & LC \\
\hline & 51. Mystus bleekeri & LC \\
\hline & 52. Mystus cavasius & LC \\
\hline & 53. Mystus malabaricus & NT \\
\hline & 54. Mystus seengtee & LC \\
\hline \multirow[t]{2}{*}{ Family- Siluridae } & 55. Ompok bimaculatus & NT \\
\hline & 56. Wallago attu & NT \\
\hline Family- Schilbidae & 57. Silonia childreni & EN A2ade+3de+4ade \\
\hline
\end{tabular}




\begin{tabular}{|l|l|l|}
\hline & 58. Neotropius khavalchor & DD \\
\hline Family- Sisoridae & 59. Glyptothorax lonah & LC \\
\hline Family- Clariidae & 60. Clarias batrachus & LC \\
\hline & 61. Heteropneustes fossilis & LC \\
\hline Order- Mugiliformes & & \\
\hline Family- Mugilidae & 62. Rhinomugil corsula & LC \\
\hline Order- Cyprinodontiformes & & \\
\hline Family- Poecilidae & 63. Gambusia affinis & LC \\
\hline Order - Synbranchiformes & & \\
\hline Family- Mastacembelidae & 64. Macrognathus pancalus & LC \\
\hline & 65. Mastacembelus armatus & LC \\
\hline Order- Perciformes & & \\
\hline Family- Ambassidae & 66. Pseudoambasis ranga & NE \\
\hline & 67. Chanda nama & LC \\
\hline Family- Cichlidae & 68. Oreochromis mossambicus & NT \\
\hline Family- Gobiidae & 69. Glossogobius giuris & LC \\
\hline Family- Channidae & 70. Channa gachua & LC \\
\hline & 71. Channa marulius & LC \\
\hline & 72. Channa punctata & LC \\
\hline & 73. Channa striatus & NE \\
\hline
\end{tabular}

IUCN: EN - Endangered, NT - Near Threatened, VU- Vulnerable, LC - Least Concern, DD - Data Deficient, NE - Not Evaluated.

Sreekantha and Ramchandra (2005) recorded 43 species in Linganamakki reservoir Sharavathi river, Solanki et al. (2011) observed sixteen species in Sanjay Sagar reservoir, Jadhav et al. (2011) recorded fifty eight species in Koyana river, Patil et al. (2011) observed twenty four fish species in Dhom dam, Supugade et al. (2011) observed 22 fish species in Yewati reservoir, Patra et al. (2011) were observed 55 species in Karala river, Mahor (2011) were reported 33 fish species in freshwater reservoir, Tighra, Rankhamb (2011) observed 26 species in Godavari river at Mudgal in district Parbhani, Thirumala (2011) were reported 33 fish species in Bhadra reservoir of Karnataka, Tawseef et al. (2012) were observed 29 fish species in Halali reservoir, Nath and Deka (2012) were reported 63 species in Chandubi tectonic lake of Assam, Kadam et al. (2012) were observed 18 species in Bori river, Bhoite and Deshpande (2012) were recorded 43 fish species in Venna river, Nagma and Khan (2013) were observed 36 fish species in district Bijnor in Western Utter Pradesh, Vyas and Vishwakarma (2013) were recorded 27 species in Jammer river. Kumar and Khanna (2014) 6 species observed at selected sites of upper stretches of river beas Himachal Pradesh and
Humbe et al. (2014) were reported 32 species in Sina Kolegoan Dam.

In the Present study 73 fish species were observed belonging to seven orders and seventeen families. The order Cypriniformes dominant with 47 species followed by order Siluriformes with 13 species, Perciformes with 8 species, Synbranchiformes with 2 species while Osteoglossiformes, Mugiliformes and Cyprinodontiformes with single species each. On the basis of percentage composition the family Cyprinidae contributing with $52 \%$ of total species followed by Bagridae $8 \%$, Balitoridae $7 \%$, Channidae 5\%, Cobitidae 4\%, Siluridae, Schilbidae, Mastacembelidae, and Ambassidae $3 \%$ and Notopteridae, Parapsilorhynchidae, Sisoridae, Mugilidae, Poecilidae, Cichlidae and Gobiidae $1 \%$.

As per to IUCN red list five species are endangered, seven near threatened, three vulnerable, forty seven least concern and two data deficient (Table No.1) species are observed.

\section{Acknowledgement}

We are very much thankful to the UGC for sanctioning the grant for Major Research Project and Principal Dr. R.V. Shejwal, Lal Bahadur Shastri College, Satara for providing the research facilities. 
Plate No. 1 - Some of the Fish species in Krishna River

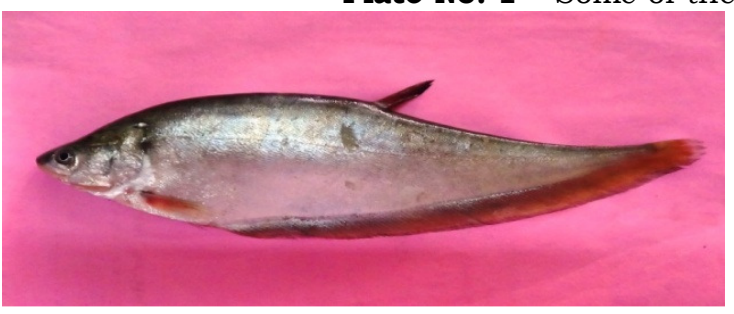

Notopterus notopterus

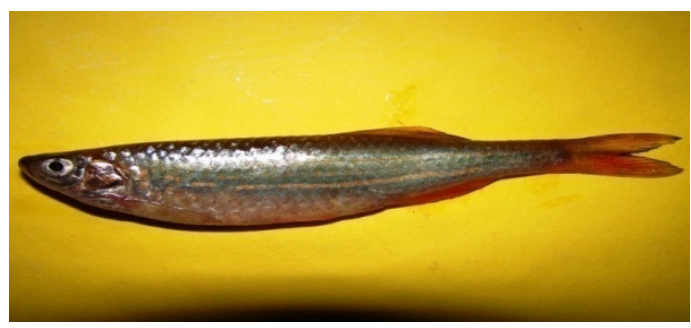

Danio malabaricus

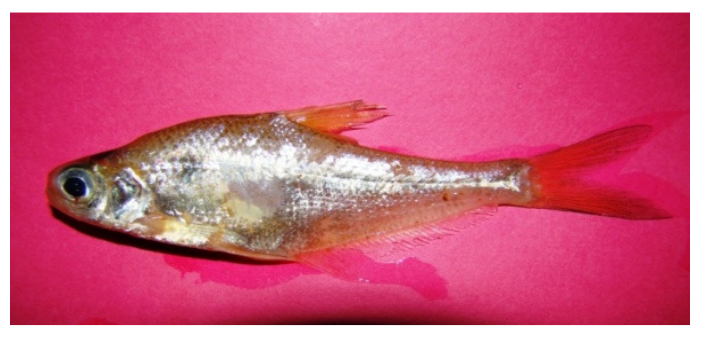

Osteobrama cotia

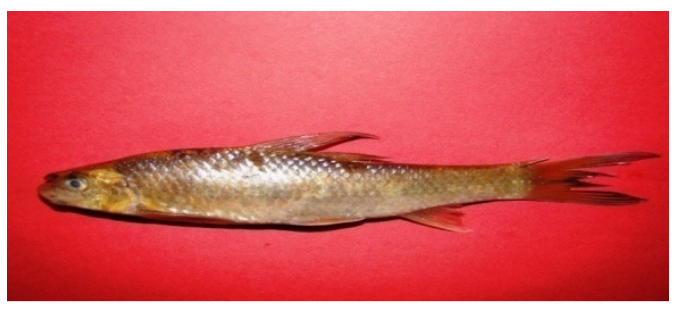

Schismatorhynchos nukta

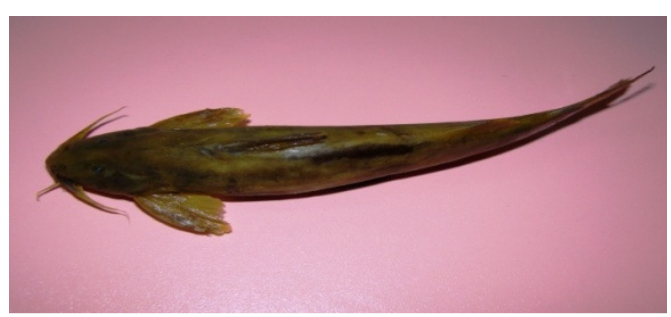

Glyptothorax lonah

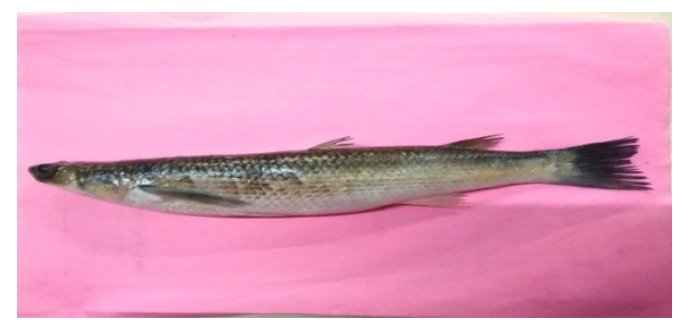

Hypophthalmichthys molitrix

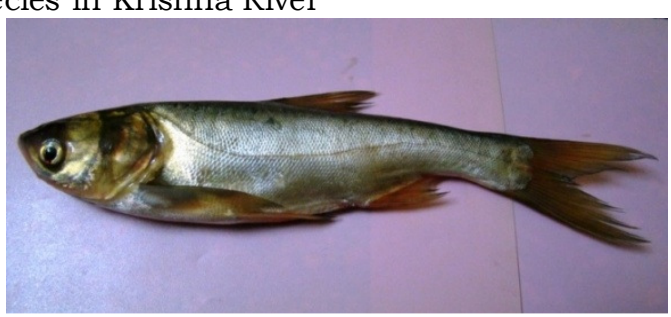

\section{Hypophthalmichthys molitrix}

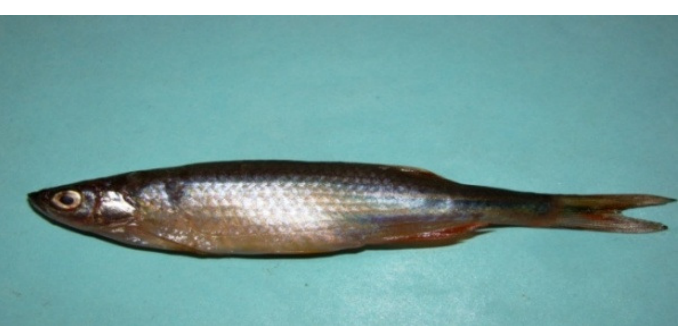

Devario aequipinnatus

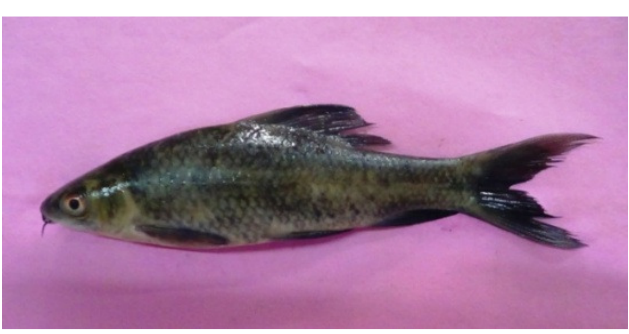

Labeo calbasu

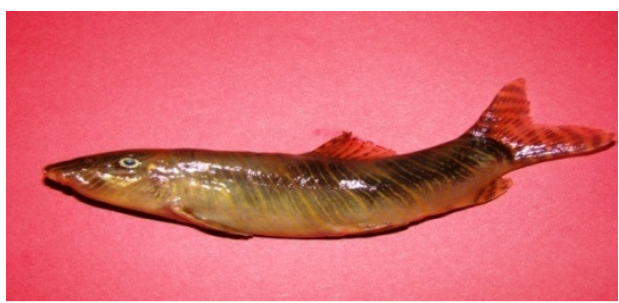

Botia striata

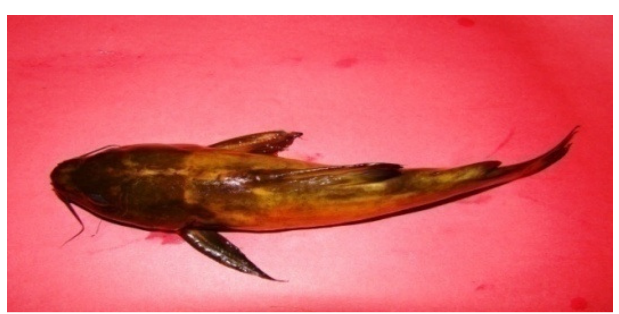

Rita rita

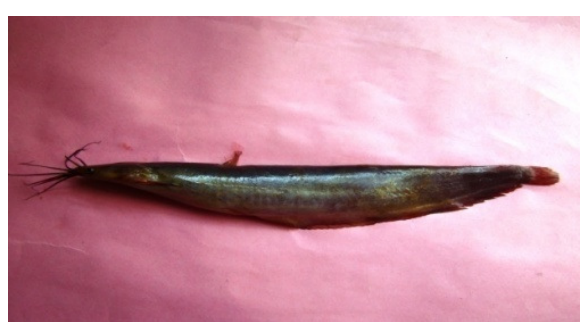

Heteropneustes fossilis 


\section{References:-}

1. Ashok Kumar and D.R. Khanna, Ichthyofaunal diversity in Upper stretches of river beas, Himachal Pradesh, India (2014), International $\mathrm{J}$. of Researches in Bioscience, Agriculture and Technology, Vol. II, Issue -2, pp 269-275.

2. Atul humbe, Swati Jadhav and Sunita Borde (2014): Diversity of Ichthyofauna from Sinakolegoan Dam Osmanabad District, Maharashtra, Weekly Science Research Journal, Vol. 1,Issue 40, pp 1-5.

3. Day F.S. (1878): The fishes of India, William and sons Ltd., Londan.

4. Goswami A.P. and Mankodi P.C.(2010): Diversity of fishes from freshwater reservoir Nyri II of Rajkot dist. Gujrat, Electronic J. of Environmental Sciences Vol.3, pp 23-26.

IUCN (2015): IUCN Red List of Threatened Species. $\quad$ Version 2014.3 $<$ www.iucnredlist.org $>$.

6. Jayram K.C. (2010): The Freshwater fishes of Indian region, Narendra Publishing House, New Delhi- 110006 (India) 2nd Edition.

7. Jadhav B.V., Kharat S.S., Raut Rupesh N., Mandar Paingankar and Neelesh Dahanukar (2011): Freshwater fish fauna of Koyna river nortern western ghats India, J. of Threatened Taxa 3(1), pp 1449-1455.

8. J. Chandrashekhra Rao, G. Simhachalam and CH Sebastian Raju (2013) A study on Ichthyofaunal Diversity, Conservation Status and Anthropogenic stress of River Champavathi, Vizianagaram District (AP) India, Asian J. Exp. Bio. Sci. Vol. 4 (3). Pp 418-425.

9. Jitesh V.K., Ananthan P.S. and Landage A.:Fish diversity and productivity of Isapur Reservoir,Maharashtra State, IJBAR,04 (12) pp 865-868.

10. Kadam M.N., P. K. Mudbe, H. K. Jadhav and S. B. Patil (2012): fish diversity of Bori river Dist. Osmanabad (M.S.) India. JSI Vol. 2(2).

11. Kharat S.S., Mandar Paingankar and neelesh Dahanukar(2012): Freshwater fish fauna of Krishna river at Wai, nortern western Ghats, India, J. of Threatened Taxa, 4(6) pp 2644-2652.

12. Mahor R.K. (2011): A survey of fish and fisheries of the freshwater reservoir Tighra, Gwalior, Madhyaprades, International Referred Res. J. Vol. II Issue 25 pp 49-50.
13. Misra K.s. (1962 ): An aid to the classification of the commercial fishes of India and Pakistan.

14. Nagma and M. Afzal Khan (2013): Studies on freshwater fish fauna of District Bijnor in Western Utter Pradesh,India,International J. Life Sci. Biotechnology and Pharma research, Vol. 2 No.3., pp 410-417.

15. Nath B. (2012): A study on fish diversity, conservation status and Anthropogenic stress of Chandubai Tectonic Lake, Assam, India ISSN 2277-8330, J.Bio.Innov1(6). Pp 148-155.

16. Patil R.G., Supugade V.B. and Patil S.S. (2011): Ichthyofauna of Dhom Da: Dist.Satara (Maharashtra) JSI special iss Vol.(2), pp 133-134.

17. Rankhambe S.v. (2011): Ichthyofaunal diversity of Godavary river at Mudgal Tq. Pathri Dist. Parbhani, Recent Research in Sci. and Tech. 3 (12), pp 11-13.

18. Sakhare V.B. (2001): Ichthyofauna of Jawalgaon reservoir in Solapur district of Maharashtra, J.Aqua.Biol. Vol.16, Nos. 1 and 2, pp 31-33.

19. Satish S. (2012): Changing paradigms of river valley settlements Krishna river valley, Inter. J.of Social Science and Interdisciplinary Res. Vol.1 Issue 7, ISSN 2277 3630, pp 145-154.

20. Solanki Pradeep, Singh Shiv, Sharma I.V. and Mathur R. (2011): Fish Fauna of Sanjay Sagar reservoir of district Guna (MP), Biological forum- An International J.3(1) pp 44-45.

21. Sreekantha and T.V. Ramchandra (2005): fish diversity in Linganamakki Reservoir, Sharavathi river, Eco. Env. and Cons.11 (3-4) pp 337-348.

22. Supugade V.B., Patil R.G., Yadav P.P. and Jadhav B.V. (2007): Diversity of Ichthyofauna, Taxonomy and Fishery from Yewati reservoir, Satara (M.S.), Proceedings of National workshop on recent trends in Biotechnology, pp 100-103.

23. Talwar,P.K., Jhingran A (1991) : Inland Fishes of India and adjacent countriesOxford -IBH Publishing, Co. Pvt. Ltd., N. Delhi Vol.1 and II, pp 115-116.

24. Tawseef Yousuf Muzahib Ibrahim, Hameem Majid,Javid Ahmad and Vipin Vyas (2012): Ichthyofaunal diversity of halali reservoir, Vidisha, Madhya Pradesh. International Journal of Scientific and 
Research Publications, Vol. 2, Issue 12, pp 17 .

25. Thirumula, S., Kiran, B.R. and Kantaraj, G.S. (2011): Fish diversity in relation to physicochemical characteristics of Bhadra reservoir of Karnataka, India, Advances in Applied Science Research, 2(5), pp 34-47.
26. Trivedy R.K and Goel P.K. (1986): Chemical and Biological Methods for water Pollution Studies, Karad, India.

27. Vipin Vyas and Kripal Singh Vishwakarma (2013): Study on Ichthyofaunal diversity of Jammer river: A tributary of Narmada river, International J. of Theoretical and Applied Science, 5 (2) pp 84-89. 